\title{
Liver Function Test on HBsAg Positive Blood Donors
}

\author{
Amrit MS Maharjan ${ }^{1}$, Bharat Jha ${ }^{2}$ and Anjana Singh ${ }^{1^{*}}$ \\ ${ }^{1}$ Central Department of Microbiology, Tribhuvan University, Kirtipur, Kathmandu, Nepal \\ ${ }^{2}$ Institute of Medicine, Tribhuvan University, Maharajgunj, Kathmandu,
}

"Corresponding author: Anjana Singh, Central Department of Microbiology, Tribhuvan University, Kirtipur, Nepal, Email: anjanas67@gmail.com

\section{ABSTRACT}

Objectives: The study was done to assess liver function test among hepatitis B surface antigen (HBsAg) positive blood donors.

Methods: Liver function test (LFT) were studied in $71 \mathrm{HBsAg}$ positive serum samples from healthy blood donors.

Results: In the study, 14(19.7Ü) serum samples showed elevated alanine aminotransferase (ALT) level above the normal range (5_35 IU/I) with mean $66.3 \pm 27.6 ; 16(22.5 \%)$ showed aspartate aminotransferase (AST) level above the normal range (5-40 IU/I) with mean 87.5 $\pm 35.7 ; 4(5.6 \%)$ serum samples showed alkaline phosphatase (ALP) level above the normal range (306 IU/I) with mean $376.5 \pm 31.5 ; 49(69 \%)$ samples were found to be below the normal albumin level $(38-51 \mathrm{gm} / \mathrm{I})$ with mean $23.9 \pm 5.76$.

Conclusion: Deviations in the serum enzymes (ALT, AST and ALP) as well as total protein and albumin level showed the silent infection of hepatitis B virus in healthy blood donors.

Key words: HBsAg, LFT, blood donors, Nepal

\section{INTRODUCTION}

Hepatitis B is one of the major diseases of mankind and is a serious global public health problem causing variety of liver diseases such as chronic hepatitis, and hepatocellular carcinoma. Of the 2 billion people who have been infected with the Hepatitis B virus (HBV), more than 350 million have chronic infections (WHO, 2000). The burden of HBV infection is heavy in most developing countries, particularly in rural areas; this burden is compounded by the high cost of prevention, management, and treatment (Rosa et al. 2015). It is estimated that about $1 \%$ of total population of Nepal is infected by hepatitis B virus (Park and Park, 1997). Transmission is mainly due to artificial inoculation of infected blood and blood products. Hepatitis infection often leaves no visible symptoms such as jaundice and liver disease because liver is a non-complaining organ. The disease is often gets severe before the symptoms occur (WHO 2000). Patients must follow periodic liver function tests for early detection of acute exacerbation of chronic hepatitis B and to avoid its progression into a severe illness (Ohta 1989).

\section{MATERIALS AND METHODS}

Blood samples were collected from blood donors by medical professionals, lab technicians and nurses using aseptic standard techniques. While drawing $350 \mathrm{ml}$ blood in blood bag, $5 \mathrm{ml}$ blood was dispensed in a small clean test tube and labeled with corresponding sample number. Serum was separated from the collected blood samples in a test tube by centrifuging at 2000 rpm for 2 minutes. The separated blood samples were serologically investigated for viral infection of hepatitis B by third generation ELISA (Enzygnost HBsAg 5.0, Dade Behring, Marburg, Germany). The 71 hepatitis B positive (HBsAg positive) serum samples were studied for liver function tests, estimation of levels of alanine aminotransferase (ALT), aspartate aminotransferase (AST), alkaline phosphatase (ALP), total protein and albumin by using test kits (RANDOX company, UK and Human Germany).

\section{RESULTS}

Table 1: LFT profile of HBsAg positive samples

\begin{tabular}{llll}
\hline \multicolumn{1}{c}{ Test } & \multicolumn{1}{c}{ normal } & \multicolumn{1}{c}{ Deviated } & \multicolumn{1}{c}{ Elevated/Lowered } \\
\hline ALT & $57(80.3 \%)$ & $14(19.7 \%)$ & Elevated \\
AST & $55(77.5 \%)$ & $16(22.5 \%)$ & Elevated \\
ALP & $67(94.4 \%)$ & $4(5.6 \%)$ & Elevated \\
Total Protein & $22(31 \%)$ & $49(69.0 \%)$ & Lowered \\
Albumin & $40(56.3 \%)$ & $31(43.7 \%)$ & Lowered \\
\hline
\end{tabular}


In the study, all the serum samples were studied for LFT which includes estimation of enzymes ALT, AST and ALP and determination of total protein and albumin level. In total number of 71 hepatitis B positive serum samples, $14(19.7 \%)$ serum samples showed elevated alanine aminotrasferase (ALT) level above the normal range (5-35 IU/I) with mean $66.3 \pm 27.6$ and $16(22.5 \%)$ showed aspartate aminotransferase (AST) level above the normal range (5-40 IU/I) with mean 87.5 \pm 35.7 .

\section{DISCUSSION}

The samples showing the elevations in ALT and AST are lesser elevation than ALP. Lesser elevations are encountered in mild acute viral hepatitis as well as in both diffuse and focal chronic liver diseases e.g. chronic active hepatitis, cirrhosis, and hepatic metastases (Burtis and Bruns 2007). Hence, the cases in the study with lesser elevations may be of mild acute hepatitis due to Hepatitis B virus infection. Tsai et al. (1997) reported that 30 of $76(39.5 \%)$ donors with raised ALT level were positive for HBsAg in a study in China. In this study only 14 of $71(19.7 \%)$ showed ALT level. As shown in the table, $4(5.6 \%)$ serum samples showed alkaline phosphatase (ALP) level above the normal range (306 IU/I) with mean $376.5 \pm 31.5$. ALP is next indicator of hepatocellular damage. Elevated levels of alkaline phosphatase activity usually reflect impaired biliary tract function (Burtis and Bruns 2007). In this case, it may be due to recent attack of hepatitis B.

In total number of $71 \mathrm{HBsAg}$ positive serum samples, 49 (69.0\%) samples were found to be below the normal range (60-80 gm/L) of total protein with mean $44.8 \pm 6.38$ and $31(43.7 \%)$ samples were found to be below the normal albumin level $(38-51 \mathrm{gm} / \mathrm{I})$ with mean $23.9 \pm 5.76$. Total protein and albumin levels in serum are two important measurements of liver function tests. Extensive liver injury may lead to decreased blood levels of albumin, prothrombin, fibrinogen, and other proteins synthesized exclusively by hepatocytes. Extensive damage of liver tissue will result in the low serum levels of total protein (Burtis and Bruns 2007). As seen in the table, most of the cases showed the decrease in the total protein and albumin level. It may be due to the damage of hepatocytes which were not able to produce the serum proteins like albumin and other proteins synthesized by them.

\section{CONCLUSION}

There is potentially a substantial risk of HBV transmission despite HBsAg testing. This is an important message for clinicians deciding to transfuse blood. The result of the study showed that the asymptomatic impairment of liver is associated with hepatitis B infection. Therefore, blood donors, who are at the risk of getting infection, should be well- informed about the mode of transmission of hepatitis B and monitoring of liver function tests. Although the incidence of transfusion-transmitted HBV has steadily reduced over the last four decades, HBV still remains the most frequent transfusion-transmitted viral infection (Niederhauser et al. 2008; Calderon et al. 2009; Kafi et al. 2009; Gulia et al. 2010; Liu et al. 2010). HBsAg serological marker in blood detection is presently the only diagnostic screening test for $\mathrm{HBV}$ infection identification in blood transfusion centres in Nepal.

\section{ACKNOWLEDGEMENTS}

Authors appreciate all the staffs of Central Blood Transfusion Service, Nepal Red Cross Society, Kathmandu; and Om Hospital and Research Center, Chabahil for their help and support during the study period.

\section{REFERENCES}

Burtis C and Bruns D (2007) Tietz Fundamentals of Clinical Chemistry. 6th edition. WB Saunders Company, USA, pp 684-892.

Calderon GM, Gonzalez-Velazquez F, Gonzalez-Bonilla CR, Novelo- Garza B, Terrazas JJ, MartinezRodriguez ML and Cortés-Márquez SR (2009) Prevalence and risk factors of hepatitis $C$ virus, hepatitis B virus and human immunodeficiency in multiply transfused recipients in Mexico. Transfusion 49: 2200-2207.

Enzygnost HBsAg 5.0, Dade Behring, Germany, edition November 2001.

Gulia S, Panda S, Sitaramam E and Reddy K (2010 Seroprevalence of hepatitis B virus infection among blood donors in local population. Int J Pathol 12(1).

Kafi -abad SA, Rezvan H, Abolghasemi H and Talebian A (2009) Prevalence and trends of human immunodeficiency virus, hepatitis B virus and hepatitis $C$ virus among blood donors in Iran 2004 through 2007. Transfusion 49: 2214-2220.

Liu Y, Li P, Li C, Zhou J, Wu C and Zhou YH (2010) Detection of hepatitis B virus DNA among accepted blood donors in Nanjing, China. Virol J 7: 193.

Niederhauser C, Mansouri B, Graziani M, Stolz M and Tinguely C (2008) Blood donorscreening: how to decrease the risk of transfusion- transmitted hepatitis B virus. Swiss Med Wkly 138-141.

Ohta Y (1989) Hepatitis B. Exptl Med, 151:794.

Park JE and Park K (1997) Viral Hepatitisin: Text Book of Preventive and Social Medicine, $15^{\text {th }}$ edition, pp 157-162.

Zampino R, Boemio A, Sagnelli C, Alessio L, Adinolfi LE, Sagnelli E and CoppolaN (2015) Hepatitis $\mathrm{B}$ virus burden in developing countries. World J Gastroenterol 21(42): 11941- 11953.

Tsai JF, Jeng JE Ho MS, Wang CS, Chang WY, Hsieh MY, Lin ZY and Tsai JH (1997) Serum alanine aminotransferase level in relation to hepatitis $B$ and $C$ virus infections among blood donors. Liver 17(1): 24-29.

World Health Organization (WHO) (2000) Hepatitis B. WHO fact sheet WHO/204, Revised October 2000. 